UDC 325.3

Submitted: 21.09 .2020

LBC 66.3(2Poc)6

Accepted: 22.01.2021

\title{
TRANSFORMATION OF THE SYSTEM OF POLITICAL SYMBOLS IN THE RUSSIAN FAR EAST IN THE $21^{\text {st }}$ CENTURY
}

\author{
Alexey V. Mikhalev \\ Buryat State University, Ulan-Ude, Russian Federation
}

\begin{abstract}
Introduction. The presented paper is a study of political symbols in the Russian Far East. We are going to discuss not only memorials, but also state symbols, works of art, texts - all the things that shape a world view. The aim of the study is to find political symbols that are universal for the entire Far East region, and to assess their political mobilization capacity. Methods and materials. The article is based upon field study materials conducted in regional centers of the Far Eastern Federal District of the Russian Federation in the spring of 2019. In theoretical terms, the work is based on symbolic politics studies of O. Yu. Malinova, S.P. Potseluev, M. Edelman. Analysis. In the course of the study, we identified several groups of political symbols with mobilization capacity. The first corpus of political symbols is related to the Soviet symbols of victory over Japan. Struggle for the use of these symbols is between the regional branches of the Communist Party and regional authorities. To put things into perspective it is important to assess the impact of Japanophobia on the further development of regional partnership with Japan. The second corpus is the symbols of Russian expansion to the Far East (worship crosses, monuments to pioneers). These symbols are a focal point of struggle between representatives of indigenous peoples, on the one hand, and Cossacks and military-patriotic organizations, on the other hand. Results. In the course of the study of the Russian Far East, we found out that, despite the complicated transformations of the past thirty years, the region is still represented as a unified symbolic space. At the same time, a number of symbolic conflicts and the devaluation of meanings have been observed.
\end{abstract}

Key words: power, symbols, politics, region, identity, Far East.

Citation. Mikhalev A.V. Transformation of the System of Political Symbols in the Russian Far East in the $21^{\text {st }}$ Century. Vestnik Volgogradskogo gosudarstvennogo universiteta. Seriya 4. Istoriya. Regionovedenie. Mezhdunarodnye otnosheniya [Science Journal of Volgograd State University. History. Area Studies. International Relations], 2021, vol. 26, no. 3, pp. 227-236. (in Russian). DOI: https://doi.org/10.15688/jvolsu4.2021.3.20

УДК 325.3

Дата поступления статьи: 21.09.2020

ББК 66.3(2Poc)6

Дата принятия статьи: 22.01.2021

\section{ТРАНСФОРМАЦИЯ СИСТЕМЫ ПОЛИТИЧЕСКИХ СИМВОЛОВ НА ДАЛЬНЕМ ВОСТОКЕ РОССИИ В ХХІ ВЕКЕ}

\author{
Алексей Викторович Михалев \\ Бурятский государственный университет им. Д. Банзарова, г. Улан-Удэ, Российская Федерация
}

Аннотация. Введение. Представленная статья посвящена изучению политических символов на Дальнем Востоке России. Речь идет не только о мемориалах, но и государственной символике, произведениях искусства, текстах, то есть обо всем, что формирует картину мира. Цель исследования - поиск универсаль구 ных для всего дальневосточного региона политических символов и оценка потенциала их политической ऽิ мобилизации. Методы и материалы. Статья базируется на материалах полевого исследования, проводив๓ шегося в столицах ДФО РФ весной 2019 года. В теоретическом плане работа опирается на исследования ¿ символической политики О.Ю. Малиновой, С.П. Поцелуева, М. Эдельмана. Анализ. В ходе исследования 气 нами выявлено несколько групп политических символов, обладающих мобилизационным потенциалом. Вопервых, советские символы победы над Японией. Борьба за использования этих символов ведется между региональными отделениями КПРФ и региональными властями. В плане прогноза на будущее важно оце(2) нить влияние японофобии на дальнейшее развитие регионального партнерства с Японией. Во-вторых, сим- 
волы освоения Дальнего Востока (поклонные кресты, памятники первопроходцам). Вокруг этих символов ведется борьба между представителями коренных народов и казачьими, а также военно-патриотическими организациями. Результаты. В ходе исследования Дальнего Востока России нами было выявлено, что, несмотря на сложные трансформации последних тридцати лет, регион по-прежнему остается единым символическим пространством. При этом прослеживаются факты наличия целого ряда символических конфликтов и девальвации смыслов.

Ключевые слова: власть, символы, политика, регион, идентичность, Дальний Восток.

Цитирование. Михалев А. В. Трансформация системы политических символов на Дальнем Востоке России в XXI веке // Вестник Волгоградского государственного университета. Серия 4, История. Регионоведение. Международные отношения. - 2021. - Т. 26, № 3. - С. 227-236. - DOI: https://doi.org/10.15688/ jvolsu4.2021.3.20

Введение. В центре исследовательского внимания - трансформация символического пространства современного Дальнего Востока России. Целью данной работы стал поиск универсальных для всего дальневосточного региона политических символов и оценка их потенциала для политической мобилизации населения. Вместе с тем мы попытаемся рассмотреть процесс коренных изменений, происходящих в этом пространстве в последние двадцать лет, выделить основные факторы устойчивости и определить возможные траектории развития ситуации. Изучение политических символов позволяет проследить не только основополагающие, «несущие конструкции» политических отношений в регионе, но и основные факторы, обеспечивающие мобилизацию населения.

Так, в 2020 г. Дальневосточный федеральный округ (ДФО) стал одним из лидеров по протестной активности населения. Пространство этого сложного в политическом и социокультурном смысле региона составляет $42 \%$ территории Российской Федерации и представляет 11 ее субъектов. Г.Э. Говорухин справедливо отмечает, что оно по-прежнему остается «недоосвоенным» [4, с. 179] и, как следствие, малоизученным. Это детерминирует кризис смыслов, которые приписываются региону из Федерального центра и в результате плохо натурализуются на местах, поэтому по сей день сложно ответить на вопрос о том, что представляет собой Дальний Восток как политическое пространство?

Основное внимание в нашем исследовании сконцентрировано на том, что Т. Мейер назвал символической политикой, осуществляемой одновременно «сверху» и «снизу» $[18$, s. 177]. В данной ситуации речь идет об об- щественно одобряемых символических акциях, которые реализует федеральная и региональная власть на Дальнем Востоке. Однако мы намеренно выводим за рамки нашего исследования инициативы «сверху», не получившие масштабной общественной поддержки, такие как брендирование региона, «Сценарии развития Восточной Сибири и российского Дальнего Востока до 2030 года» и т. п.

Ключевыми акторами символической политики в регионе являются субфедеральные органы власти, КПРФ, казачьи организации, национально-культурные центры народов, проживающих в ДФО РФ, японские и корейские НКО. Каждый из этих акторов имеет собственный набор политически значимых символов и свою модель представлений о Дальнем Востоке. Эти модели - «Партизанский край», «Земля трех казачьих войск», «Желтороссия», «Внешняя Манчжурия», а также многочисленные этнонациональные образы - формируют многообразие воображаемых образов Дальнего Востока России. Многие из них противоречат друг другу, что может привести к политическим конфликтам, но символы, лежащие в их основе, становятся универсальными. Они могут использоваться для мобилизации населения различными политическими акторами и по-разному интерпретироваться.

Указанные процессы непосредственно связаны с трансформацией региональной политической мифологии, с изменениями локальных представлений о пространстве Дальнего Востока - того, что географы называют «идеей места» [5], поэтому основной акцент в данной статье делается на переменах, происходящих в политико-символической сфере. Новые символы и новые смыслы, не выходящие за пределы региона, стали основой для соли- 
дарности, которую некоторые авторы называют дальневосточной идентичностью [3]. Этот феномен, несмотря на социальную депривацию и выраженный протестный потенциал, является сугубо российским, резко выделяющимся на фоне интеграционных процессов в Восточной Азии.

Немаловажным для данной работы является участие в дискуссии по поводу принципиальной возможности существования на Дальнем Востоке единого символического пространства. Данная точка зрения опирается на тезис о том, что в условиях нескольких волн колонизации региона единая общность жителей Дальнего Востока России так и не была сформирована [20]. Автор же данной статьи придерживается иного мнения, согласно которому подобная общность сформировалась и представляет собой один из примеров фронтирной идентичности [15]. Подобный тип идентификации предполагает множественность моделей самопрезентации и политической лояльности. Здесь важно упомянуть имена ученых, труды которых оказали большое влияние на развитие темы символической политики на Дальнем Востоке. Речь идет о работах Г.Э. Говорухина [4], Л.Е. Бляхера [3], А. Вуда [20], С. Дэвис [15], А.В. Ремнева [10], И. Саблина [13], И.О. Пешкова [19].

Методы и материалы. В теоретическом плане работа базируется на исследованиях символической политики О.Ю. Малиновой [6], С.П. Поцелуева [9], М. Эдельмана [16]. Вслед за О.Ю. Малиновой мы опираемся на утверждение о том, что «символическая политика осуществляется в публичной сфере, то есть виртуальном пространстве, где в более или менее открытом режиме обсуждаются социально значимые проблемы, формируется общественное мнение, конструируются и переопределяются коллективные идентичности, иными словами имеет место конкуренция разных способов интерпретации социальной реальности» [7, с. 12].

В методологическом плане автор статьи опирался на теоретические разработки Н. Фэркло. Был проведен критический дискурс-анализ региональной литературы и материалов масс-медиа за последние десять лет. В выборку попали газеты, являющиеся официальными печатными органами дальне- восточных субъектов РФ, а также материалы электронных СМИ. Особое внимание было уделено книгам о Дальнем Востоке, сформировавшим основные преставления о его мифогеографии и топонимике. Применение метода дискурс-анализа позволило проследить трансформацию политических смыслов, влияющих на представления о регионе и об «идее места».

В течение 2018-2019 гг. были проведены экспедиции по Дальнему Востоку РФ. Цель экспедиций состояла в сборе материалов, касающихся символической политики в регионе. В указанный период сбор эмпирического материала проводился во всех столицах субъектов ДФО РФ. В центре внимания были музеи и памятники. Была проведена серия экспертных интервью с представителями местных парламентов, а также с краеведами. Анализ пространственных объектов памяти был проведен с опорой на методику Go-along, разработанную М. Кузенбах [17]. Суть этого метода состоит в следующем: интервьюер передвигается по городу вместе с респондентом, задавая уточняющие вопросы относительно того, на что они посмотрели, куда пошли, каков их опыт передвижения по этим маршрутам и т. д. При использовании метода Go-along чувство места обостряется благодаря тому, что передвижение по нему осуществляется в настоящий момент. В итоге мы собрали сведения о символическом пространстве федерального округа. Методика Go-along позволила получить данные об актуальных изменениях городской политической топонимики и региональной символики [17].

Анализ. Дальний Восток как географическое понятие - это символ, в котором отражается многогранность экономических укладов и политических предпочтений. Именно эта часть азиатской России в цивилизационном плане тесно связана с буддизмом и шаманизмом, распространенными в соседних странах Восточной Азии. Это дает основание некоторым исследователям рассматривать данный регион как контактную зону - фронтир. Как метко отметил историк Алан Вуд: «Холодный фронтир России» [20]. Эта важная черта региона, которая хорошо объясняет сложившуюся миграционную ситуацию с отрицательным сальдо. Русские диаспоры в странах Азии 


\section{ИНСТИТУЦИОНАЛИЗАЦИЯ РЕГИОНАЛЬНОГО ПРОСТРАНСТВА РФ}

(прежде всего в Китае и Южной Корее), китайские мигранты в Приамурье и Приморье все это результат фронтирного положения. Именно поэтому И. Левитов в начале XX в. ввел в оборот понятие Желтороссии - пространства от Байкала до Тихого океана: «Это в большей степени желтая Россия. У нас есть белая Россия, малая Россия и т. д., почему бы не быть желтой России»? В его представлениях Манчжурия виделась «Русской Индией», а Формоза (Тайвань) «Желтым Босфором». Однако за множеством перечисленных выше эпитетов нет мнения, сформированного непосредственно на Дальнем Востоке [2].

Дальний Восток - это российский фронтир в Восточной Азии, интегрированный в систему экономических и политических отношений. Этот регион имеет историко-культурные связи с Китаем, Японией и Кореей (Северной и Южной). Само понятие Дальний Восток наполнено множественными политическими смыслами [19]. В географии Российской империи и СССР Восток как масштабная культурно-историческая категория делился на Среднюю Азию, Кавказ и Дальний Восток. Последний предполагал обширную территорию от Байкала до Тихого океана, населенную азиатскими народами. Это пространство на уровне категориального аппарата именовалось различными способами: от Азиатской России до Желтороссии.

Отдельного внимания заслуживает прилагательное «Дальний» по отношению к огромной области, составляющей едва ли не половину страны. «Дальний» в системе географии власти понимается как отдаленный от центра принятия решений и системы распределения ресурсов, поэтому требующий особого внимания. Отсюда возникает основная смысловая дихотомия удаленности, с одной стороны, предполагающая депривацию, а с другой - привилегированный доступ к ресурсам. Особенно наглядно это прослеживается на примере контраста трех исторических периодов. Так, в СССР существовала система привилегированного обеспечения Дальнего Востока ресурсами. В период реформ 1990-х гг. эти территории оказались вне сферы внимания Центра, но уже во время президентства В.В. Путина регион стал «национальным приоритетом на весь XXI век».
Возвращаясь к современным смыслам и символам, на наш взгляд, важно привести цитату из книги В. Авченко «Правый руль»: «У Дальнего Востока голоса нет, мое Приморье корчится безъязыким. До “материковой" России доходят отрывочные сведения о разгуливающих по нашим городам то ли тиграх, то ли китайцах, компанию которым составляют немногочисленные русские. Сплошь - бандиты, барыги и контрабандисты, не желающие созидательно трудиться» [1, с. 85]. Из этой цитаты мы выводим следующий аспект нашего исследования - социальное конструирования пространства в литературе. Речь идет о Дальнем Востоке как хронотопе, то есть о воображаемом в художественной литературе регионе.

Указанные В. Авченко стереотипы, связанные с Дальним Востоком, возникли не одномоментно. Они конструировались в отечественной литературе на протяжении многих лет. Едва ли не первыми в этом ряду были путевые записки А.П. Чехова «Остров Сахалин». Дальнейшее «литературное освоение» региона связано с именами Н. Арсеньева и Н. Матвеева. Но только начиная с «Тигроловов» И. Багряного и «Диких пчел» И. Басаргина Дальний Восток предстает массовому читателю как особое место - таежная Азия. На страницах этих книг, равно как и книги Ю. Семенова «Пароль не нужен», пространство тайги становится мистической территорией, определяющей истинные характеры людей и нормы их жизни. В произведениях И. Басаргина цивилизующую миссию в тайге выполняют старообрядцы, бежавшие от государства и пытающиеся жить по библейским законам. Они устанавливают норму некоего естественного права, регулирующего жизнь людей вне государства. Его произведения «По законам тайги», «Черный дьявол», «В горах тигровых» сформировали мифологию Дальнего Востока. Именно эта интерпретация тайги стала тем самым фреймом, который воспроизводится на протяжении уже половины столетия.

Что же касается политического пространства, то оно конструировалось в романах В. Пикуля. Его книги «Богатство», «Каторга» и «Крейсера» формируют образ неосвоенности, тотальной коррупции и героизма жителей 
Дальнего Востока. Цикл романов В. Пикуля описывает русско-японское противостояние, воспроизводя дискурс внешней угрозы и необходимости эффективного государства для наиболее удаленной восточной окраины империи. Именно Пикуль вписал представления о богатом ресурсами регионе в систему геополитической борьбы мировых держав. Образ опасного фронтира, населенного каторжанами, контрабандистами, шпионами и военными, пытающимися контролировать огромные пространства, окончательно закрепился в романах «Крейсера» и «Каторга».

Литературный Дальний Восток стал символом, определяющим региональную идентичность. Наличие собственного богатого литературного наследия и внимание столичных авторов внесли самый большой вклад в формирование региональной мифологии и в воспроизводство исторических травм. При этом на уровне хронотопа регион представляется во вневременном пространстве начала XX в. в таежных партизанских дебрях в условиях нависающей внешнеполитической угрозы.

Как свидетельствуют собранные нами эмпирические данные, в столицах дальневосточных субъектов наиболее значимой символикой, маркирующей регион, являются объекты, связанные с партизанской борьбой. Весь ландшафт от Улан-Удэ до Владивостока отмечен памятниками партизанам, Партизанскими улицами и проспектами, даже одним городом (Партизанск). Подобная смысловая насыщенность отсылает нас к наследию советской эпохи. Первоначальный смысл партизанской символики был напрямую связан с идеей противостояния белогвардейцам и интервентам. Именно в это время, по меткому выражению К. Шмитта: «прежняя арена империи разрушалась и перевертывалась вверх дном большая сцена официальной публичности» $[14$, с. 126]. Символ красного партизана закреплял в массовом сознании более крупный геополитический образ Дальнего Востока как региона-крепости, как русского национального аванпоста во враждебном международном окружении [13]. После окончания Второй мировой войны метафора крепости стала вновь востребованной в условиях почти двадцатилетнего советско-китайского противостояния.
Однако в условиях перемен постсоветского периода, с началом политики «Поворота на Восток», образ партизана стал трансформироваться. Но важно отметить, что в условиях десоветизации в 1990-е гг. памятники и улицы, связанные с партизанской борьбой, не были демонтированы или заменены. Образ партизана как защитника малой Родины, напротив, укоренился, став символом борьбы за права региона. Современная интерпретация символов партизанской борьбы все больше отсылает нас к теории партизана К. Шмитта. Переоценка событий Гражданской войны в России через призму противостояния на Дальнем Востоке партизанских и атаманских отрядов снова сделала актуальным опыт столетней давности. Согласно К. Шмитту партизан имеет теллурический характер, он защищает участок земли, с которым автохтонно связан [14, с. 139]. В итоге символы, которые еще тридцать лет назад ассоциировались с коммунистической идеологией, стали символами региона. Именно регионализм в той или иной форме не позволил полностью реабилитировать белое движение на Дальнем Востоке, тесно сотрудничавшее с японскими интервентами.

С другой стороны, именно с партизанами Дальнего Востока связывается восстание 1925 г. [2, с. 163]. Оно было спровоцировано усилением давления советских органов и началом коммунистических социальных экспериментов. Партизаны стали символом борьбы как с произволом казачьих атаманов, так и с централизованным давлением советской власти. В этих рамках они выражают интересы местного населения в большей степени, нежели какой-либо власти. Кроме того, дальневосточный партизан как символ не национален - партизанскими командирами были буряты, якуты, китайцы, корейцы и представители других народов.

Сегодня партизан как символ места и иррегулярной борьбы остается одним из ключевых образов, характеризующих регион. Генеалогию локального дискурса «противостояния с варягами» можно проследить отталкиваясь от этого образа. Сформировавшиеся в условиях сложных перипетий $1990-$ х гг. сильные сети, представляющие местные группы влияния, обращаются к риторикам, которые 
можно охарактеризовать как интуитивное шмиттианство, так как они основаны на противопоставлении местных, укорененных и «варягов». На наш взгляд, подобная пропозиция объективирована самой ареной политического действия, то есть символическим пространством ДФО.

Другим значимым символом дальневосточной идентичности стали острова курильской гряды: Кунашир, Шикотан, Хабомаи и Итуруп. Вопрос об их принадлежности (на них заявила свои территориальные претензии Япония) для жителей Дальнего Востока стал одной из основ региональной солидарности. Начиная с конца 1980-х гг. японские структуры, такие как организации бывших военнопленных, начали формировать дискурс примирения на региональном уровне. В частности, при финансовой поддержке японских структур был установлен мемориал покаяния за военные преступления, совершенные на территории Амурской области в период интервенции. Однако на уровне региональной памяти выстроить диалог, ориентированный на примирение, оказалось невозможным.

Травма японской интервенции по сей день остается актуальной в силу того, что противостояние между СССР и Японией продолжалось более двадцати лет. Официально закрепленный в историографии период одной только интервенции длился с 1918 по 1925 год. На уровне региональных СМИ тема военных преступлений по-прежнему актуальна: «Желая отомстить за поражение в Николаевске-наАмуре, японские каратели организовали в Приморье массовую резню - было убито и ранено свыше пяти тысяч человек, в том числе в топке паровоза сожжен один из руководителей Дальнего Востока Сергей Лазо. В апреле японцы силой разогнали во Владивостоке и других городах Приморья и Хабаровске органы власти, разоружили местные войска. Под предлогом “защиты жизни и собственности соотечественников” в этом же месяце японские войска оккупировали Северный Сахалин» [12].

Тема возврата Курильских островов на территории Дальнего Востока воспринимается так остро в первую очередь в силу периферийности побед в региональной истории по отношению к общему нарративу отечествен- ной истории. Во-вторых, сформированный «партизанский» дискурс легитимизирует исключительное право на неприкосновенность территории Дальнего Востока, закрепленной за хранящем региональную память его населением. При этом в зависимости от субъекта РФ острота темы японской интервенции существенно варьируется. Наиболее актуальной она остается в Сахалинской и Амурской областях, Приморском, Хабаровском, Забайкальском краях и Бурятии.

На определенном этапе образ Японии оказался закрепленным на региональном уровне как образ «Другого» со всеми негативными коннотациями. Кроме того, в условиях открытых границ в XXI в. этот образ получил поддержку из Китая и Кореи, чье культурное влияние на Дальнем Востоке достаточно велико. Причины этого лежат в историческом наследии почти полувековой экспансии Японской империи в Восточной Азии в XX веке. На уровне войн памяти в этом регионе еще не расставлены все точки над і в деле признания ответственности за военные преступления. Отсюда и скептическое отношение к территориальным претензиям современного японского руководства.

Проблема освоения Дальнего Востока, по мнению большинства исследователей, является наиболее значимой темой для региона. Освоение, освоенность, недоосвоенность стали едва ли не основными смыслами, приписываемыми изучаемому нами пространству на протяжении всей его истории. В этом контексте интересно взглянуть на памятники первопроходцам и их значение в символическом пространстве региона. Однако памятники казакам-первопроходцам всегда являлись достаточно неоднозначными символами и по сей день вызывают ожесточенные споры среди населения региона. Символика казачьего возрождения, получившая распространение в 2000-е гг, напрямую конфликтует с символами партизанского движения [8].

Стоит отметить, что Дальний Восток это территория трех казачьих войск: Забайкальского, Амурского и Уссурийского со столицами в Чите, Благовещенске и Хабаровске. Начавшееся в 1990-е гг. возрождение казачества привело к запросу на соответствующие символы в политическом пространстве 
региона. Однако попытки захвата символического пространства столкнулись с противодействием со стороны коренных народов, рассматривающих казаков как колонизаторов [8].

На уровне войсковых столиц наибольшего успеха возрождение казачества добилось в Чите. В столице Забайкалья был установлен памятник атаману-первопроходцу Петру Бекетову, также в его честь были названы улицы как в Чите, так и в других населенных пунктах края. В Благовещенске же тема первопроходцев XVII в. трансформировалась в нарратив о первопоселенцах XIX столетия. Вместо памятника Пояркову в городе установлен мемориал казакам-первопоселенцам, основавшим в 1856 г. Усть-Зейский военный пост. В свою очередь, в Хабаровске находится старейший во всем ДФО установленный в 1958 г. памятник первопроходцу Ерофею Хабарову $[8$, с. 330$]$.

Возрождение казачества встречает негативную реакцию в национальных республиках ДФО: в Бурятии и Якутии. Отношение к казакам как к колонизаторам и завоевателям формирует мощное противодействие со стороны общественности, препятствующее появлению каких-либо масштабных политически значимых символов. Другой темой, вызывающей не менее ожесточенные споры, является память об атаманах, возглавлявших белое движение в регионе. Протесты против установки памятника атаману Г.М. Семенову, организованные при поддержке местного КРПФ, привели к тому, что проект был провален на уровне общественных слушаний, вследствие этого вопрос о памятниках атаманам И.М. Гамову и И.П. Калмыкову ни разу не поднимался на официальном уровне [8]. Надо отметить, что «атаманские» режимы, несмотря на то что формально они относятся к белому движению, зачастую представляли собой полупартизанские, полубандитские образования. При этом ни А.В. Колчак, ни его преемники так и не сумели полностью подчинить себе атаманов, терроризировавших местное население.

В итоге символы казачьего освоения региона сегодня стали одной из причин разобщения населения. Многонациональный и многоконфессиональный Дальний Восток России с его травматической памятью даже в XXI в. не готов ассоциировать пространство с историей завоевания и подчинения. Здесь же важно упомянуть и справедливое замечание А.В. Ремнева о том, что уже к XIX в. казачество в этом регионе перестало быть достаточно твердой опорой российской государственности [11]. Скептическое отношение к казачеству, сформировавшееся еще в Российской империи, по сей день сохраняет устоявшиеся негативные коннотации. В советский же период казачество ассоциировалось с белой эмиграцией и коллаборационистами, поэтому символическое пространство региона отсылает лишь к атаманам-первопроходцам, идеализированным русскими народниками, а вслед за ними и революционерами [8].

Символическое пространство Дальнего Востока на протяжении последних двадцати лет трансформируется, приобретая новые контуры. Это непосредственно связано с изменениями и самого региона, и конфигурации власти в нем. Так, в 2018 г. в состав округа вернулись еще два субъекта - Бурятия и Забайкальский край, - исторически являющиеся частью этого региона. Несмотря на изменение границ, символическое пространство осталось по-прежнему относительно гомогенным: так и Бурятия, и Забайкалье на протяжении большей части XX в. считались частью Дальнего Востока. Исходя из этого можем наметить три основных сценария развития символического пространства ДФО.

Первый связан с преобладанием травмы 1990-х годов. Примером тому служит памятник челноку (Памятник труду и оптимизму Амурских предпринимателей) в Благовещенске и нарратив о энергетической катастрофе. Последний весьма актуален по сей день в силу одного из самых высоких тарифов на электроэнергию в России. «Замерзающий регион», «ледяной фронтир»- подобные эпитеты систематически фигурируют в региональной прессе. Кроме того, на уровне коллективной памяти жителей региона «инфраструктурная травма» остается едва ли не основой локальной солидарности. В этих условиях партизанская символика приобретает новые, более конфронтационные коннотации. В итоге Дальний Восток получает все шансы стать пространством социального кризиса и протеста. 
Второй сценарий ориентирован на формирование у региона собственной знаковосимволической системы, вписанной в общефедеральные тренды. Примером тому является празднование на государственном уровне 3 Сентября - дня окончания Второй мировой войны и разгрома милитаристской Японии. Это свидетельствует о значимости истории борьбы за восточные рубежи в национальном масштабе - на протяжении нескольких лет депутаты сахалинского Законодательного собрания отстаивали право на этот праздник. Разгром Японии является значимым нарративом для всей Восточной Азии, для Китая, Монголии, Северной и Южной Кореи, поэтому, на наш взгляд, наиболее благоприятным развитием событий для региона будет актуализация символов, подчеркивающих значимость событий его истории в глобальном контексте.

Третий сценарий - это интеграция в символическое пространство так называемой Большой Азии. Начиная с 1990-х гг. неоднократно фиксировались случаи появления альтернативной географии российского Дальнего Востока с китайскими или японскими названиями. Однако важно обратить внимание не только на картографию и топонимику, но и на региональные риторики, время от времени отсылающие к идее «открытия региона» для экономического и культурного сотрудничества с сопредельными государствами. Во многом это связано с комплексом противоречий в отношении принятия и непринятия собственной истории и символики. Влияние местных национализмов также вносит большой деструктивный вклад в формирование общей идеи российской дальневосточной идентичности. Однако на данный момент вероятность развития какого-либо из трех указанных сценариев крайне неочевидна. Пока «точка невозврата» еще не пройдена, поэтому остается возможность развития ситуации как в позитивном, так и негативном русле.

Результаты. В ходе исследования Дальнего Востока России нами было выявлено, что, несмотря на сложные трансформации последних тридцати лет, регион по-прежнему остается единым символическим пространством. При этом зафиксировано наличие целого ряда символических конфликтов и искажения исто- рических смыслов. Важное значение приобретают травматические аспекты памяти и символической политики. Речь идет о наследии рыночных реформ и распада СССР, существенно повлиявших на самосознание жителей Дальнего Востока. Несмотря на это, мы выделили несколько устойчивых сегментов регионального символического поля, обеспечивающих ему единство и стабильность.

Во-первых, это представление о пространстве. Исторически сложилось так, что понятие Дальний Восток a priori предполагает окраинность и депривацию с ярко выраженными ориенталистскими характеристиками. Однако именно эти противоречивые понятия, нагруженные множеством смыслов, определяют его как часть России. В итоге возникла формула, разграничивающая пространство: Восточная Азия - это заграница, Дальний Восток - это Россия. К содержанию региональной топонимики непосредственное отношение имеет литература, авторы которой в разное время экзотизировали и мифологизировали регион.

Во-вторых, атаманщина и партизанщина. Это две группы символов, фактически противостоящих друг другу. С одной стороны, это памятники партизанам, натурализовавшиеся и устойчивые символы региона, доставшиеся в наследство от советской эпохи. Они достаточно универсальны и хорошо адаптируются даже к местным национализмам (бурятскому и якутскому). С другой стороны, это памятники атаманам-первопроходцам, большая часть которых была установлена в 2000-е годы. Они вызывают неоднозначную реакцию населения региона, особенно в национальных республиках, в связи с откровенно колониальными смыслами, которые содержит история освоения Дальнего Востока. При этом символы казачьей колонизации так или иначе присутствуют в публичном пространстве, вызывая ожесточенные дискуссии.

Третьим символом является миф о тайге, масштабно описанный в художественной литературе и песнях. Тайга выступает как символ богатства региона природными ресурсами и как некое мистическое пространство. В региональной мифологии оно противопоставляется цивилизованному миру с его несправедливыми законами и недостатками. По 
мере развития ресурсоориентированной экономики тайга становится все более значимым геополитическим фактором.

\section{СПИСОК ЛИТЕРАТУРЫ}

1. Авченко, В. Правый руль / В. Авченко. M. : Ad Marginem, 2012. $-368 \mathrm{c}$.

2. Бляхер, Л. Е. Зомия на Амуре, или Государственный порядок против порядка вне государства / Л. Е. Бляхер, М. Л. Бляхер // Полития. - 2018. № 1 (88). - C. 148-171. - DOI: 10.30570/2078-50892018-88-1-148-171.

3. Бляхер, Л. Е. Региональная самоидентификация и трансграничные практики на Дальнем Boстоке России / Л. Е. Бляхер // Пространственная экономика. - 2005. - № 1. - С. 117-132.

4. Говорухин, Г. Э. Недоосвоенные территории освоенного пространства (экономико-социологический аспект) / Г. Э. Говорухин, Г. Р. Осипов // Вестник ТОГУ. - 2007. - № 2 (5). - С. 179-196.

5. Замятин, Д. Н. Власть пространства и пространство власти: географические образы в политике и международных отношениях / Д. Н. Замятин. - М. : РОССПЭН, 2004. -352 c.

6. Малинова, О. Ю. Конструирование смыслов: Исследование символической политики в современной России / О. Ю. Малинова. - М. : ИНИОН PAH, 2013. $-421 \mathrm{c}$.

7. Малинова, О. Ю. Символическая политика: контуры проблемного поля / О. Ю. Малинова // Символическая политика. Вып. 1 : Конструирование представлений о прошлом как властный ресурс. - М. : ИНИОН РАН, 2012. - С. 5-16.

8. Михалев, А. В. Часовые фронтира: памятники атаманам и политика коммеморации в условиях дальневосточного пограничья / А. В. Михалев // Политика памяти в современной России и странах Восточной Европы. Акторы, институты, нарративы : коллектив. моногр. / под ред. А. И. Миллера, Д. В. Ефременко. - СПб. : Изд-во Европ. ун-та в Санкт-Петербурге, 2020. - С. 322-335.

9. Поцелуев, С. П. «Символическая политика»: к истории концепта / С. П. Поцелуев // Символическая политика. Вып. 1. Конструирование представлений о прошлом как властный ресурс. - М. : ИНИОНРАН, 2012. - С. 17-54.

10. Ремнев, А. В. Россия Дальнего Востока. Имперская география власти XIX - начала XX веков / А. В. Ремнев. - Омск : Изд-во Омск. гос. ун-та, 2004. $-552 \mathrm{c}$.

11. Ремнев, А. В. «Русское дело» на азиатских окраинах: «русскость» под угрозой или «сомнительные культуртрегеры» / А. В. Ремнев, Н. Г. Суворова // Ab impeio. - 2008. - № 2. - C. 157-222.
12. Русские Курилы. История и современность. Сборник документов по истории формирования русско-японской и советско-японской границы / А. Кошкин, А. Плотников, В. Зиланов, С. Пономарев. М. : Алгоритм, 2015. - 430 c.

13. Саблин, И. Дальневосточная республика. От идеи до ликвидации / И. Саблин. - М. : НЛО, $2020 .-480 \mathrm{c}$.

14. Шмитт, К. Теория партизана / К. Шмитт. М. : Праксис, 2007. - 301 c.

15. Davis, S. The Russian Far East. The last frontier / S. Davis. - London ; New York : Routlege, 2003. $-155 \mathrm{p}$.

16. Edelman, M. The Symbolic Uses of Politics / M. Edelman. - Urbana etc : University of Illinois Press, 1972. $-201 \mathrm{p}$.

17. Kusenbach, M. Street phenomenology: the goalong as ethnographic research tool / M. Kusenbach // Ethnography. - 2003. - Vol. 4, № 4. - P. 455-485.

18. Meyer, T. Die Inszenierung des Scheins. Voraussetzungen und Folgen symbolischer Politik. Essay-Montage / T. Meyer. - Frankfurt am Main : Suhrkamp, 1992. $-203 \mathrm{~s}$.

19. Peshkov, I. In the shadow of 'frontier disloyalty' at Russia - China-Mongolia border zones / I. Peshkov // History and anthropology. - 2017. Vol. 27. - P. 429-444. - DOI: https://doi.org/10.1080/ 02757206.2017.1351358.

20. Wood, A. Russia's Frozen Frontier. A history of Siberia and Russian Far East 1581-1991 / A. Wood. L. : Bloomsbury, 2011. -272 p.

\section{REFERENCES}

1. Avchenko V. Pravyj rul [The Right Wheel]. Moscow, Ad Marginem Publ., 2012. 368 p.

2. Bliakher L.E., Bliakher M.L. Zomija na Amure, ili Gosudarstvennyj porjadok protiv porjadka vne gosudarstva [Zomia on the Amur, or State Order Against the Order Outside of State]. Politea, 2018, no. 1 (88), pp. 148-171. DOI: 10.30570/2078-5089-201888-1-148-171.

3. Bliakher L.E. Regionalnaja samoidentifikacija i transgranichnye praktiki na Dalnem Vostoke Rossii [Regional Self-Identification and Transborder Practices in Russian the East]. Prostranstvennaja jekonomika [Spatial Economics], 2005, no. 1, pp. 117-132.

4. Govoruhin G.Je., Osipov G.R. Nedoosvoennye territorii osvoennogo prostranstva (jekonomikosociologicheskij aspekt) [Underdeveloped Territories of the Developed Space (Economic and Sociological Aspect)]. Vestnik TOGU [Bulletin of PNU], 2007, no. 2 (5), pp. 179-196.

5. Zamjatin D.N. Vlast prostranstva $i$ prostranstvo vlasti: geograficheskie obrazy v politike 
i mezhdunarodnyh otnoshenijah [The Power of Space and the Space of Power: Geographical Images in Politics and International Relations]. Moscow, ROSSPEN Publ., 2004. 352 p.

6. Malinova O.Yu. Konstruirovanie smyslov: Issledovanie simvolicheskoj politiki v sovremennoj Rossii [Meaning Construction: A Study of Symbolic Politics in Contemporary Russia]. Moscow, INION RAN, 2013. $421 \mathrm{p}$.

7. Malinova O.Yu. Simvolicheskaja politika: kontury problemnogo polja [Symbolic Politics: Contours of the Problem Field]. Simvolicheskaja politika. Vyp. 1: Konstruirovanie predstavlenij o proshlom kak vlastnyj resurs [Symbolic Politics. Vol. 1: Constructing Representations of the Past as an Imperious Resource]. Moscow, INION RAN, 2012, pp. 5-16.

8. Mikhalev A.V. Chasovye frontira: pamjatniki atamanam i politika kommemoracii v uslovijah dalnevostochnogo pogranichja [Frontier Watchmen: Atamans Monuments and the Policy of Commemoration Within Far East Frontiers]. Politika pamjati v sovremennoj Rossii i stranah Vostochnoj Evropy. Aktory, instituty, narrativy: kollektiv. monogr. [The Politics of Memory in Modern Russia and the Countries of Eastern Europe. Actors, Institutions, Narratives: A Collective Monograph]. Saint Petersburg, Izd-vo Evropejskogo universiteta v Sankt-Peterburge, 2020, pp. 322-335.

9. Poceluev S.P. «Simvolicheskaja politika»: k istorii koncepta ["Symbolic Politics": To the History of the Concept]. Simvolicheskaja politika. Vyp. 1: Konstruirovanie predstavlenij o proshlom kak vlastnyj resurs [Symbolic Politics. Vol. 1: Constructing Representations of the Past as an Imperious Resource]. Moscow, INION RAN, 2012, pp. 17-54.

10. Remnev A.V. Rossija Dalnego Vostoka. Imperskaja geografija vlasti XIX-nachala XXvekov [Russia of the Far East. Imperial Geography of Power in the $19^{\text {th }}-$ Early $20^{\text {th }}$ Centuries]. Omsk, Izd-vo Omskogo gosudarstvennogo universiteta, 2004. 552 p.

11. Remnev A.V., Suvorova N.G. «Russkoe delo» na aziatskih okrainah: «russkost» pod ugrozoj ili «somnitelnye kulturtregery» ["The Russian Cause" on the Asiatic Borderlands: The "Russianness" Under Threat and "Questionable Kulturträgers"]. Ab impeio, 2008, no. 2, pp. 157-222.

12. Koshkin A., Plotnikov A., Zilanov V., Ponomarev S. Russkie Kurily. Istorija i sovremennost. Sbornik dokumentov po istorii formirovanija russkojaponskoj i sovetsko-japonskoj granicy [Russian Kuriles. History and Modernity. Collection of Documents on the History of the Formation of the Russian-Japanese and Soviet-Japanese Borders]. Moscow, Algoritm Publ., 2015. 430 p.

13. Sablin I. Dalnevostochnaja respublika. Ot idei do likvidacii [Far Eastern Republic. From Idea to Liquidation]. Moscow, NLO, 2020. 480 p.

14. Shmitt K. Teorija partizana [Theory of the Partisan]. Moscow, Praksis, 2007.301 p.

15. Davis S. The Russian Far East. The Last Frontier. London and New York, Routlege, 2003. 155 p.

16. Edelman M. The Symbolic Uses of Politics. Urbana etc, University of Illinois Press, 1972. 201 p.

17. Kusenbach M. Street Phenomenology: The GoAlong as Ethnographic Research Tool. Ethnography, 2003, vol. 4, no. 4, pp. 455-485.

18. Meyer T. Die Inszenierung des Scheins. Voraussetzungen und Folgen Symbolischer Politik. Essay-Montage. Frankfurt am Main, Suhrkamp, 1992. $203 \mathrm{~s}$.

19. Peshkov I. In the Shadow of Frontier Disloyalty at Russia - China - Mongolia Border Zones. History and Anthropology, 2017, vol. 27, pp. 429-444. DOI: https://doi.org/10.1080/02757206.2017.1351358.

20. Wood A. Russia's Frozen Frontier. A History of Siberia and Russian Far East 1581-1991. London, Bloomsbury, 2011. 272 p.

\section{Information About the Author}

Alexey V. Mikhalev, Doctor of Sciences (Politics), Associate Professor, Director, Center of Political Transformation Studies, Buryat State University, Smolina St, 24a, 670000 Ulan-Ude, Russian Federation, mihalew80@mail.ru, https://orcid.org/0000-0001-7069-2338

\section{Информация об авторе}

Алексей Викторович Михалев, доктор политических наук, доцент, директор Центра изучения политических трансформаций, Бурятский государственный университет им. Д. Банзарова, ул. Смолина, 24a, 670000 г. Улан-Удэ, Российская Федерация, mihalew80@mail.ru, https://orcid.org/0000-0001-7069-2338 